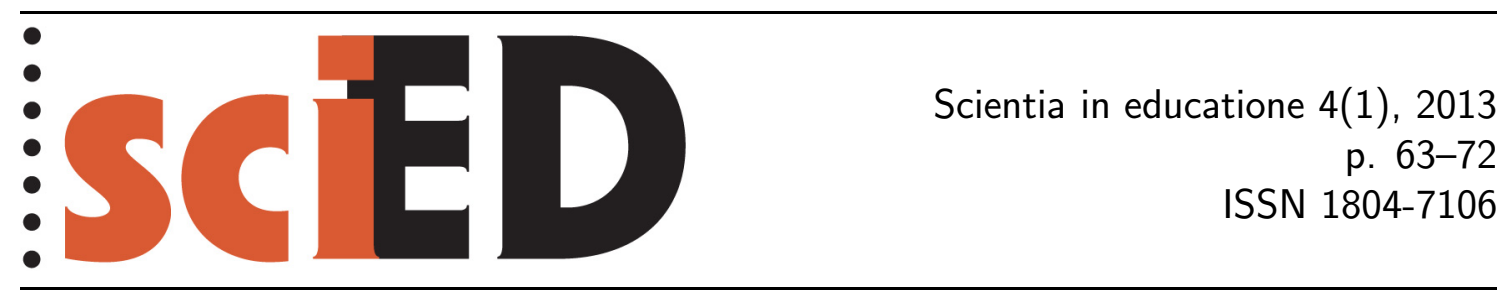

\title{
Strategie řešení úloh ve výuce fyziky na středních školách
}

\author{
Marie Snětinová, Zdeňka Koupilová
}

\begin{abstract}
Abstrakt
Řešení kvantitativních fyzikálních úloh má v českém vzdělávacím systému dlouholetou tradici. Proto jsme se rozhodli zabývat otázkou, jakým způsobem by mohli středoškolští žáci zlepšit své dovednosti v řešení úloh. Hlavním cílem prezentované studie bylo zjistit, jaké metody či kroky při řešení úloh žáci vědomě používají a jaké faktory ovlivňují výběr těchto metod. Vytvořili jsme proto dva dotazníky, které jsme zadali žákům středních škol (ve věku 15-19 let). Jeden dotazník se skládal pouze z otevřených otázek, druhý obsahoval jak otevřené otázky, tak uzavřené otázky se škálou. Oba dotazníky se zabývají strategiemi řešení úloh. Z výsledků průzkumu vyplynulo, že mnoho žáků, použivá strategie, které mohou vést $\mathrm{k}$ vyřešení jednoduchých úloh, ale nejsou optimální $\mathrm{k}$ rozvoji dovedností potřebných $\mathrm{k}$ řešení fyzikálních úloh. Popsaný průzkum je jednou částí rozsáhlejš́ho výzkumu, který se zabývá řešením úloh ve výuce fyziky.
\end{abstract}

Klíčová slova: řešení úloh, strategie, fyzika, stř̌ední škola.

\section{Problem Solving Strategies in High School Physics Lectures}

\begin{abstract}
Solving quantitative physics tasks has a long tradition in Czech education system. Therefore, we study how high school students can improve their problem solving skills in physics lectures. The goal of the first part of the study described in this paper was to find out what methods or steps students claim they use during solving physics tasks and if there are any factors that affect choosing the these methods. Two questionnaires for students concerning use of chosen problem solving strategies were composed - one containing open format questions only and the second with open format questions and rating scale questions. The respondents of the questionnaire survey were high school students (students at the age of 15 to 19), who are attending physics courses during their study. We found that many students use strategies that can be efficient for getting answers of simple problems, but they are not appropriate for developing problem solving skills. The questionnaire survey is a part of more extensive research concerned with problem solving in physics education.
\end{abstract}

Key words: problem solving, strategy, physics, high school. 


\section{INTRODUCTION}

Solving quantitative physics tasks has a long tradition in Czech education system. It can be demonstrated, for example, by a large number of problems in physics textbooks and problem collections (e.g. Lepil et al., 1995; Nahodil, 2011; Žák, 2011). On the other hand, it is necessary to admit that many students - not only in the Czech Republic - struggle with many difficulties when solving physics tasks (Byun, Ha, Lee, 2008).

Therefore, we decided to realize a questionnaire survey concerned with problem solving strategies at Czech high schools. The main goal of this survey was to discover students' view of solving physics tasks. The questionnaire survey analyzed what methods and strategies students claim that they use during solving physics tasks and if there are any aspects that influence choice of these methods.

The described survey follows the literature search presented in Snetinova (2011) and it is a part of more extensive ongoing research concerned with the problem solving in physics education. One of final aims is to develop detailed methodical materials for teachers and worksheets for students. These materials will help students to increase their abilities to solve physics tasks.

Results of this survey were partly presented at the World Conference on Physics Education in Istanbul in July 2012 and will be published in the proceedings of the conference. In this paper, we present a more detailed description of the study and more extensive discussion of its results.

\section{ThEORETICAL BACKGROUND}

One of the possibilities how to divide physics tasks is classification on quantitative and qualitative tasks. The difference is that in solving quantitative tasks mathematical methods are used. However, solving qualitative as well as quantitative tasks assume qualitative insight into the problem (Svoboda, Kolářová, 2006). According Van Heuvelen (1991), students are often unable to reason qualitatively about physical process and they use primitive formula-centered problem solving methods. In addition, there is a big contrast between expert and novice problem solvers in using different problem solving strategies. Harper (2006) states three important examples of these differences:

- Experts view problem solving as a process, while novices think it is a recall task;

- Experts classify problems based on deep structure, while novices classify based on surface features;

- Experts use nonmathematical representations, like graphs, charts, and diagrams extensively, while novices tend not to.

Ogilvie (2009) divides problem solving strategies into two groups - limiting strategies that "may work well for well-structured, end-of-chapter exercises, but they begin to fail as the problems become more complex" and expansive strategies that "can be readily applied to more ill-structured challenges". He also adds that "these (expansive) strategies have also been identified as characteristic for expert problem solving approaches". As problem solving strategies, Ogilvie (2009) means steps that lead to the achievement of a specific goal (e.g. solution of a physics task).

Several studies (e.g. Van Heuvelen, 1993; Bagno, Eylon, 1997; Lederman, 2009) claim that it is possible to mitigate the limiting strategies by using special approaches and students can be taught more appropriate techniques how to solve physics tasks. 


\section{Methods}

The presented survey was inspired by a research described in Ogilvie (2009). He defined strategies that were used as a foundation for creation of one part of the questionnaire research. The survey proceeds from a literature research (Snetinova, 2011). The survey is only a part of a larger research concerned with solving quantitative physics tasks. The whole research has a qualitative character.

\subsection{PARTICIPANTS}

Several Czech high school teachers were asked to participate in a questionnaire survey. Teachers who agreed with the participation were instructed how to process the questionnaires with students. The participated schools were from Prague, other bigger as well as smaller cities. Besides five standard state high schools, two private high schools and one technical school were included into the selection.

Respondents of the survey were from Czech high schools (students at the age of 15 to 19), who are attending physics lessons during their study. The number of respondents in particular classes is stated in Table 1.

Table 1: Number of respondents in particular classes and particular questionnaires

\begin{tabular}{|l|c|c|c|}
\hline \multirow{2}{*}{ Class (students' age) } & \multicolumn{2}{|c|}{ Number of respondents } & \multirow{2}{*}{ In total } \\
\cline { 2 - 3 } & $\mathrm{S} 1$ & $\mathrm{~S} 2$ & \\
\hline 1. class $(15-16)$ & 142 & 114 & 256 \\
\hline 2. class $(16-17)$ & 88 & 97 & 185 \\
\hline 3. class $(17-18)$ & 96 & 87 & 183 \\
\hline 4. class $(18-19)$ & 82 & 67 & 149 \\
\hline In total & $\mathbf{4 0 8}$ & $\mathbf{3 6 5}$ & $\mathbf{7 7 3}$ \\
\hline
\end{tabular}

\subsection{TOOLS AND PROCEDURE}

We decided to use questionnaire as a data collection method, because it provided us to gain sufficient amount of data in a relatively short time. The survey contains two different students' questionnaires (marked S1 and S2). Both questionnaires were designed similarly on purpose.

The questionnaire S1 (answered by 408 respondents) consisted of nine rating scale questions (see Table 2) that concerned with using problem solving strategies. These strategies, including their description, were created according to Ogilvie (2009) and in cooperation with experts in physics education and with an experienced high school teacher (13 years of practice). They are divided into two categories - limiting strategies (marked L1-L4) and expansive strategies (marked E1-E5). These terms were taken from Ogilvie (2009). Besides the rating scale questions questionnaire S1 contained five open format question (see Table 3).

The second questionnaire S2 (365 respondents) consisted of five open format questions only (see Table 3). Three questions are the same as in S1. Instead of rating scale question the strategies that students use during solving physics tasks were covered by open questions. 
Table 2: Description of problem solving strategies in rating scale question of questionnaire S1

\begin{tabular}{|l|l|}
\hline Short name of strategy & Description of strategy used in the questionnaire \\
\hline $\begin{array}{l}\text { L1: Listing known and } \\
\text { unknown quantities }\end{array}$ & $\begin{array}{l}\text { "After reading the assignment I make a list of } \\
\text { known and unknown quantities." }\end{array}$ \\
\hline $\begin{array}{l}\text { L2: Rolodex equation } \\
\text { matching }\end{array}$ & $\begin{array}{l}\text { "I try to select an equation largely because the } \\
\text { equation has the same variables that are listed } \\
\text { in the assignment." }\end{array}$ \\
\hline $\begin{array}{l}\text { L3: Prior tasks in text or } \\
\text { lecture }\end{array}$ & $\begin{array}{l}\text { "I try to find similar task (in textbook, notes or } \\
\text { elsewhere)." }\end{array}$ \\
\hline $\begin{array}{l}\text { L4: Prior experiments in } \\
\text { lecture }\end{array}$ & $\begin{array}{l}\text { "I try to remember if we did some experiment } \\
\text { similar to the task during lecture." }\end{array}$ \\
\hline E1: Sub-problems & $\begin{array}{l}\text { "I try to solve the task step by step and divide } \\
\text { it into smaller sub-problems." }\end{array}$ \\
\hline E2: Real situation & $\begin{array}{l}\text { "I try to imagine the problem in a real } \\
\text { situation." }\end{array}$ \\
\hline E3: Concept first & $\begin{array}{l}\text { "First I think about the ideas and physics } \\
\text { concepts involved in the problem." }\end{array}$ \\
\hline E4: Rational thought & $\begin{array}{l}\text { "First I solve the task in my mind and then I do } \\
\text { arithmetic." }\end{array}$ \\
\hline E5: Diagram & $\begin{array}{l}\text { "I try to draw some diagram (sketch, chart,... } \\
\text { to every task." }\end{array}$ \\
\hline
\end{tabular}

Table 3: List of open format questions from both questionnaires

\begin{tabular}{|c|c|}
\hline Questionnaire S1 & Questionnaire S2 \\
\hline $\begin{array}{l}\text { 1. What is your biggest problem } \\
\text { during problem solving in physics? } \\
\text { 2. Is there anything that helps you } \\
\text { with solving physics tasks? } \\
\text { 3. What is - according to you - the } \\
\text { purpose of solving physics tasks? } \\
\text { 4. Do you think that you can use these } \\
\text { approaches also in other situations? In } \\
\text { which ones? } \\
5 \text {. Which steps were recommended or } \\
\text { shown to you to help you to solve } \\
\text { physics problems? }\end{array}$ & $\begin{array}{l}\text { 1. Do you have any proven steps you } \\
\text { use during problem solving in physics? } \\
\text { What methods do you use if you don't } \\
\text { know how to solve the problem at first } \\
\text { sight? } \\
\text { 2. To what do you pay attention } \\
\text { during solving physics tasks? } \\
\text { 3. What is - according to you - the } \\
\text { purpose of solving physics tasks? } \\
\text { 4. Do you think that you can use these } \\
\text { approaches even in other situations? } \\
\text { In which ones? } \\
5 \text {. Which steps were recommended or } \\
\text { shown to you to help you solve physics } \\
\text { problems? }\end{array}$ \\
\hline
\end{tabular}

We chose this design to gain the good image about the students' strategies. Open format questions enabled to more easily investigate, what was the attitude of high school students to the solving of physics tasks and what obstacles, according their opinion, they contended with. The open format question in S2 offered to students an opportunity to describe strategies in their own words. On the basis of our previous experiences with questionnaire surveys, we know that in written questionnaire teenage respondents can have problems with formulation of their own 
answers. They tend to answer very shortly and write the first idea only. Moreover, some steps done during problem solving students don't perceive as "a strategy" and that's why they would not mention them in the open format question. Because of these assumptions we put the list of the particular strategies in the rating scale questions in questionnaire S1. Students rated how often they used these strategies regardless if they used them knowingly and saw them as problem solving strategies.

\section{Findings}

\subsection{Students PROBLEM SOLVING STRATEGIES}

One of the main goals of the students' questionnaire survey was to determine which strategies and methods students indicate they use in solving physics problems. Nine strategies were described in the questionnaire S1 (see Table 2) and students marked how often they used these strategies. Results of this part of survey are stated in Figure 1. The labels L1-L4 and E1-E5 indicate whether the strategy is considered to be limiting (L) or expansive (E) (according to Ogilvie, 2009).

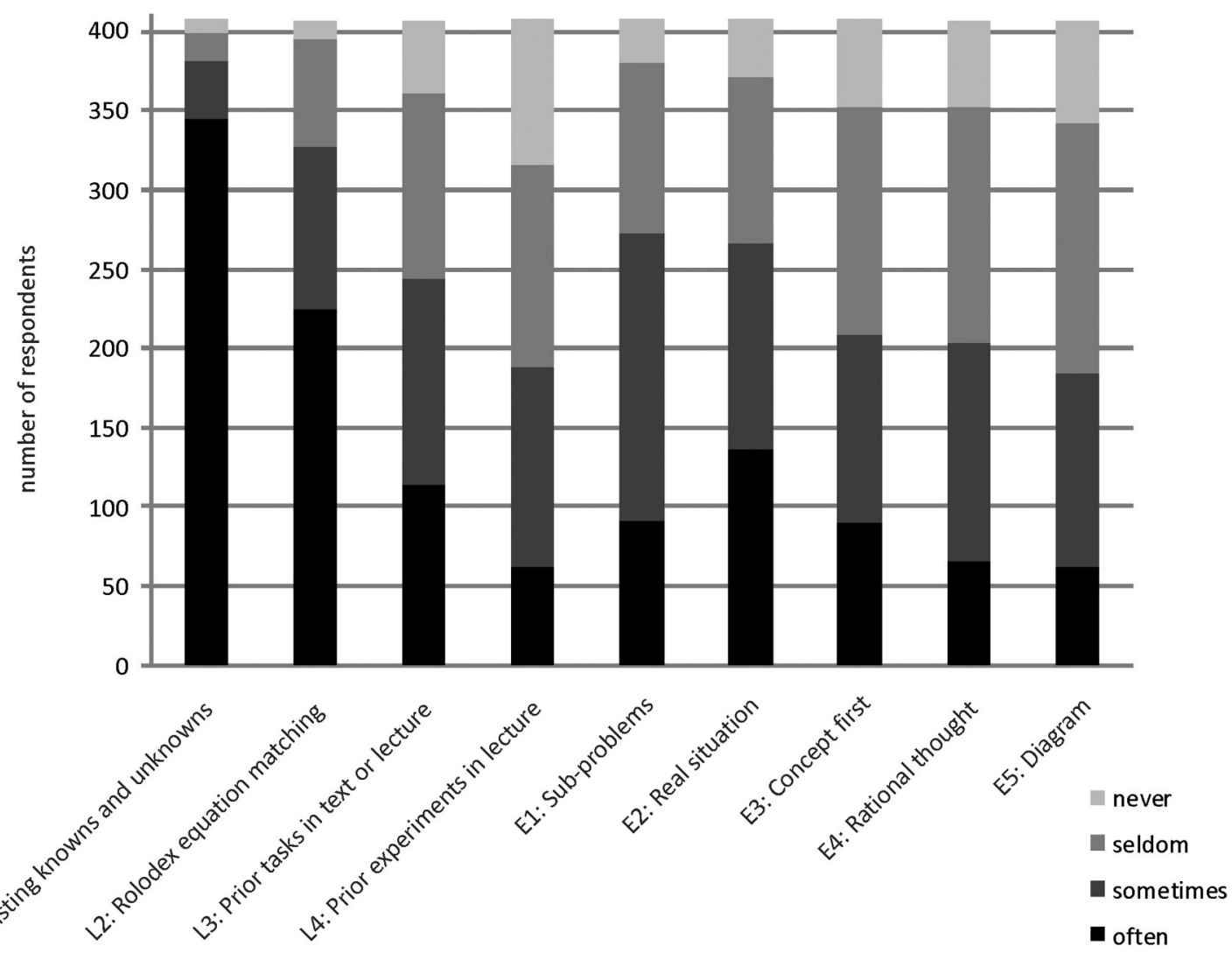

Figure 1: Students' answers to the question: "How often do you use strategies mentioned below?" from the questionnaire S1

The strategies in Figure 1 are arranged according to the sum of answers "often" and "sometimes", limiting strategies are placed first and expansive strategies follow. A closer examination of Figure 1 shows that students very often stated that they used the limiting strategies. It can be also seen that the most often mentioned strategy is L1: Listing known and unknown quantities. This is a relatively unsurprising result, because Czech students are taught since primary school to write this list just below 
the assignment. The second most often stated strategy is L2: Rolodex equation matching. Although this approach can be efficient for getting answers, it is far from optimal for improving problem solving skills and understanding the physics concepts. According to Buffler \& Allie (1993), using of this strategy can be caused by "the instructor may mention what principles or concepts are being applied, but generally only writes down the associated equations" approach when illustrating physics concepts by solving particular problems.

One of the least used strategies, in students' view, is E5: Diagrams. According for example to Leonard, Durfense \& Mestre (1996) or Van Heuvelen (1991), using of this strategy differs between beginners (students) and experts (teachers or physicists). Scarl (2003) even claims that "most people think in pictures and find a diagram a help even in problems that have no obvious geometrical part".

If we focus on using problem-solving strategies in particular classes, no significant difference is evident (see Figure 2). The survey shows that students' problem-solving methods and strategies are invariable during high school attendance.

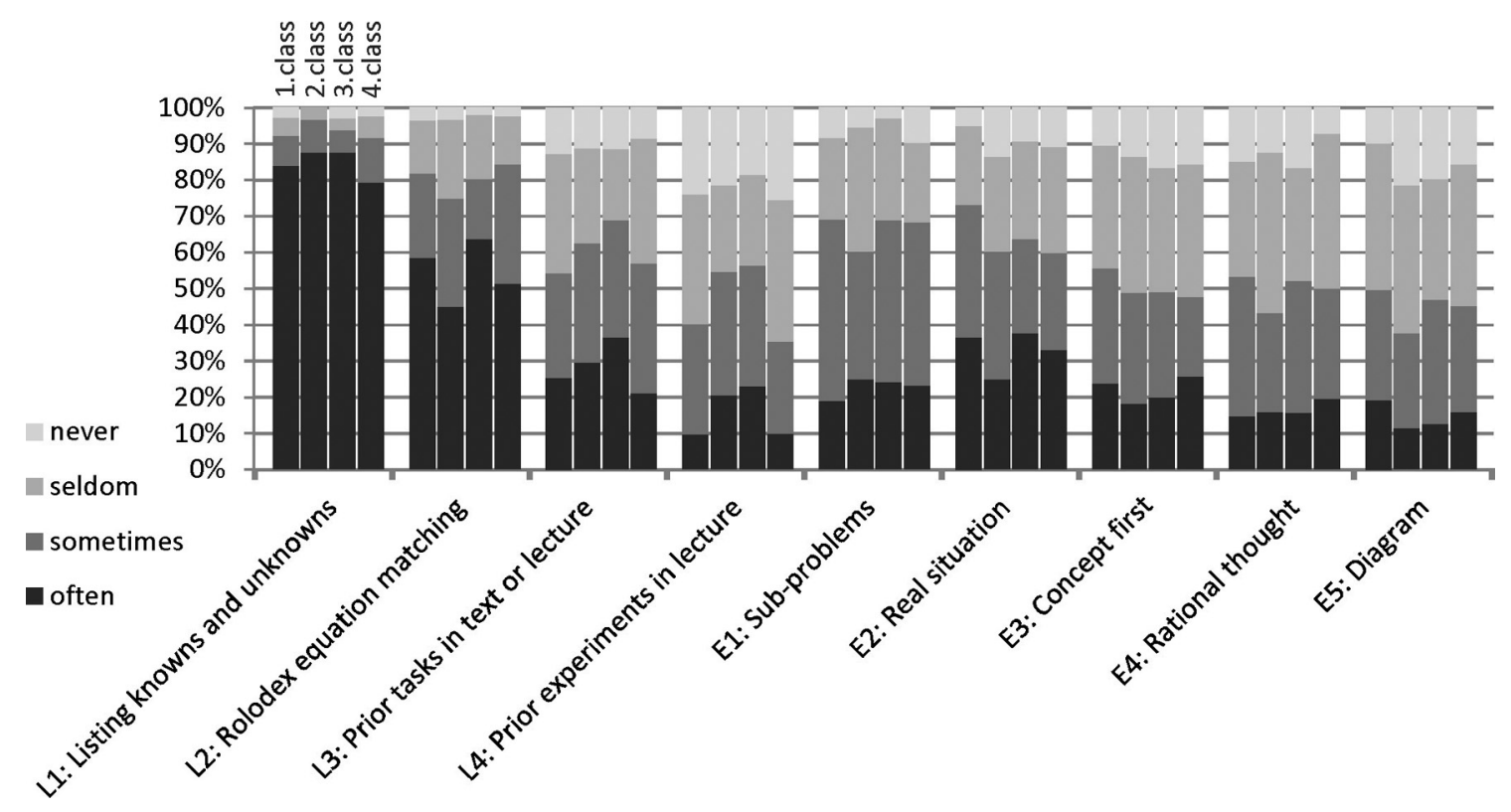

Figure 2: Using problem-solving strategies in particular classes (questionnaire S1)

Students' answers to the question in questionnaire S2 concerning the problem solving strategies were classified into several categories. These categories were created by researcher on the basis of respondents' answers. The most frequently mentioned strategies and the number of respondents are stated in Table 4. The strategies are arranged according to the frequency of responses.

It is necessary to remark that our assumption was confirmed and students really often stated only one strategy as an answer. Probably the students wrote the first thing that crossed their mind and they did not have any reason to think about the question more deeply.

It can be seen that the most often stated strategy in the questionnaire S2 is Rolodex equation matching (93 of respondents). On the other hand, many expansive strategies (e.g. E1, E3, E4, Commentating on the task, Classifying important facts) were stated only by a small number of respondents.

The most frequently mentioned strategy - except the strategies not covered by rating scale questions in questionnaire $\mathrm{S} 1$ - is Thinking about the problem (29 of respondents). However, this method can partly overlap with other strategies, for 
Table 4: Mentioned methods and strategies from the questionnaire S2

\begin{tabular}{|l|c|}
\hline Mentioned strategies & Number of responses \\
\hline Rolodex equation matching (L2) & 93 \\
\hline Listing known and unknown quantities (L1) & 36 \\
\hline Diagram (E5) & 29 \\
\hline Thinking about the problem & 28 \\
\hline Cooperation & 25 \\
\hline Rereading the assignment several times & 23 \\
\hline Trying to combine "everything with everything" & 21 \\
\hline Postponement of the task for later & 19 \\
\hline Real situation (E2) & 19 \\
\hline Prior tasks in text or lecture (L3) & 7 \\
\hline Thinking back to formerly learned theory & 5 \\
\hline Simplification of the task & 5 \\
\hline Concept first (E3) & 5 \\
\hline I do at least what I can & 4 \\
\hline Sub-problems (E1) & 4 \\
\hline Classifying important facts & 4 \\
\hline Finding a solution in text or lecture & 2 \\
\hline Rational thought (E4) & 1 \\
\hline Prior experiments in lecture (L4) & 32 \\
\hline Commentating on the task & 23 \\
\hline Rule of three & 29 \\
\hline
\end{tabular}

example Concept first or Real situation. This category of students' response was established for such answers in which students did not state exactly or in more detail how they think about the problem.

\subsection{DisCUSSION OF REMAINING OPEN FORMAT QUESTIONS}

Conclusions gained from the questionnaire survey are stated below. Each generalized result mentioned below is accompanied by original students' answers from questionnaire. We believe that all results can be interesting and useful in practice.

1. Students should know why some strategies or methods are required or recommended from them. Many students understand the solving of physics tasks only as one of several way of marking. Therefore, it is important even for teachers themselves to think about the purpose of solving tasks in physics and what skills it develops. 
Student: "It was often recommended to me to draw pictures. But what is the purpose of this if I don't know any idea about the situation and I can't draw?"

Student: "When I'm solving a task, it helps me to know what the point of doing it is."

2. Students should have a feeling that they can gain correct solution by their own when solving physics task. Our result correspond with Harper (2006): "Many students believe that when you read a problem, either you know how to solve it, or you don't. The instructor may appear to know exactly how to solve a problem the moment she lays eyes on it. One way to address this mistaken belief might be to make the process more transparent to the class."

Student: "In my opinion, the most common approach that is used in explaining some task is: to take a look at the task and immediately know what's going on. But I can't use this approach."

Student: "Our teacher solves the task by herself and she thinks that we understand the steps. But it is not true."

3. It is important to keep a cool head during solving physics tasks and do not get stressed out. In accordance with the students' responses, Scarl (2003) claims that it is good to think optimistically. Below are stated several answer to the question "Do you have any proven steps you use during problem solving in physics?"

Student: "Don't panic!"

Student: "I calm myself down and I think hard about the problem."

Student: "I try to calm myself down and I reread the assignment."

4. Other interesting observation is that students do not realize that solving physics tasks is not only about getting or guessing the correct answer.

According to authors' experiences, it is important for students to be able to formulate their thoughts - either on paper or verbally. Teachers have then an opportunity to consider, if the students' thoughts are correct and they can draw students' attention to their shortcomings.

Student: "I try to solve the task by my guess, but teachers mostly want some formulas."

\section{FUtURE PLANS}

The presented questionnaire survey is only one part of a more extensive research inquiring into solving quantitative physics tasks. We will continue by creating of methodical materials for high school teachers and worksheets for students that should contribute to development of students' problem solving skills. In the next year, these materials will be integrated into physics lessons at several Czech high schools. Usability and applicability of the materials will be explored by using case studies.

\section{Conclusion}

The main aim of the presented questionnaire survey was to find out what strategies and methods students claim to use and what their view on problem solving is gen- 
erally. The survey showed that the most often mentioned strategies are so-called limiting strategies, that can be efficient for getting answers, but they are not appropriate for developing of problem solving skills. Conclusions gained from the open format questions of the questionnaires were presented in the contribution. These results were completed by several examples of students' answers. We found both, the conclusions as well as the examples of answers, as inspiring for many teachers.

\section{ACKNOWLEDGEMENT}

The present work was supported by the Charles University Grant Agency (grant no. 374711). The authors thank the teachers from high schools who assigned the questionnaires to students during their lectures.

\section{BIBLIOGRAPHY}

BAGNO, E., EYLON, B. S. From problem solving to a knowledge structure: An example from the domain of the domain of electromagnetism. American Journal of Physics, 65(8), 1997, p. 726-736.

BUFFLER, A., ALLIE, S. Towards an active learning environment in physics: developing problem solving skills through cooperative learning. Proceedings of the Annual Conference of the South African Association of Academic Development (ed. By C. Boughey, B. Leibowitz), Bellville, 1993, p. 15-29.

BYUN, T., HA, S., LEE, G. Identifying student difficulty in problem solving process via the framework of the House Model (HM). Proceedings of the Physics Education Research Conference, Vol. 1064, Edmonton, Alberta: AIP, 2008, p. 87-90.

HARPER, K. A. Student Problem-Solving Behaviors. The Physics Teacher, 44(4), 2006, p. 250-251.

LEDERMAN, E. Journey into Problem Solving: A Gift from Polya. The Physics Teacher, 47(2), 2009, p. 94-97.

LEONARD, W. J., DURFENSE, R. J., MESTRE, J. P. Using qualitative problemsolving strategies to highlight the role of conceptual knowledge in solving problems. American Journal of Physics, 64(12), 1996, p. 1495-1503.

LEPIL, O., et al. Fyzika: Sbírka úloh pro střední školy. Praha : Prometheus, 1995.

NAHODIL, J. Sbirka úloh z fyziky kolem nás pro střední školy. Praha: Prometheus, 2011.

OGILVIE, C. A. Changes in students' problem-solving strategies in a course that includes context-rich, multifaceted problems. Physical Review Special Topics Physics Education Research, 5(2), 2009.

SCARL, D. How to Solve Problems for Success in Freshman Physics, Engineering and Beyond, Glen Cove, New York : Dosoris Press, 2003.

SNETINOVA, M. Quantitative physics tasks. WDS'11 Proceedings of Contributed Papers: Part III - Physics (ed. by J. Safrankova \& J. Pavlu), Prague : Matfyzpress, 2011, p. 61-65. 
SVOBODA, E., Kolářová, R. Didaktika fyziky základní a střední školy: vybrané kapitoly. Praha: Karolinum, 2006.

VAN HEUVELEN, A. Learning to think like a physicist: A review of research-based instructional strategies. American Journal of Physics, 59(10), 1991, p. 891-897.

ŽÁK, V. Fyzikální úlohy pro středni školy. Praha : Prometheus, 2011.

Mgr. Marie Snětinová - E-mail: marie.snetinova@mff.cuni.cz

RNDr. Zdeňka Koupilová, Ph.D.

Univerzita Karlova v Praze, MFF

Katedra didaktiky fyziky, Czech Republic 